\title{
Experimental study on soot characteristics of laminar co-flow ethylene diffused flame under air atmosphere
}

\author{
Jing $\mathrm{Xu}^{* 1}$, Ping Jiang ${ }^{\mathbf{1}}$, Xiaoling Liang ${ }^{\mathbf{1}}$, and Ruijiao Tian ${ }^{\mathbf{1}}$ \\ ${ }^{1}$ School of Mechanical Engineering, Wanjiang University of Technology, Ma'anshan, 243031, China
}

\begin{abstract}
The morphological characteristics of ethylene flame under different working conditions were photographed and analyzed by CCD camera, the temperature distribution at different positions of flame was measured and analyzed by the thermocouple, and the characteristics of soot in ethylene diffusing flame under different airflow rates were studied by means of SiC fiber sampling and subsequent TEM image analysis. The results showed that: (1) when the airflow was unchanged, the flame height increased with the increase of ethylene flow, and the flame height changed with the increase of ethylene flow in a linear relationship. When the ethylene flow increased from $120 \mathrm{~mL} / \mathrm{min}$ to $180 \mathrm{~mL} / \mathrm{min}$, the flame height increased by about $60 \%$. The flame height increased slightly with the increase in air flow. (2) The flame edge temperature was always greater than the central temperature of the corresponding height. Under the same working condition, the average temperature was $87.5{ }^{\circ} \mathrm{C}$ higher. (3) Along the flame axis, soot particles follow the process of nucleation, growth, condensation, agglomeration, and oxidation, and the four processes coexist. Once the flow rate of ethylene is determined, the generation of soot in each stage will lag when the flow rate of air increases.
\end{abstract}

\section{Introduction}

In recent years, with rapid economic development, the world is also faced with resource and environmental pressure. Therefore, the utilization of hydrocarbon fuel has become a research hotspot ${ }^{[1-4]}$. However, during the combustion of hydrocarbon fuel, pollutants such as soot will inevitably be produced, which will affect the environment and human health. Therefore, the efficient and clean use of hydrocarbon fuels becomes very important.

$\mathrm{Du}$ et al. ${ }^{[5]}$ studied the influence of $\mathrm{CO}_{2}$ on the formation of soot particles in ethylene flames and believed that the chemical action of $\mathrm{CO}_{2}$ inhibited the formation of soot. Liu et al. ${ }^{[6]}$ theoretically considered chemical action, dilution action, and thermal action, analyzed the effect of adding $\mathrm{CO}_{2}$ on ethylene combustion, and reached the same conclusion. $\mathrm{Hu}$ et al. [7] studied the influence of $\mathrm{CO}_{2}$ on the propagation velocity of methane flame under the $\mathrm{O}_{2} / \mathrm{CO}_{2}$ atmosphere and quantitatively calculated the degree of influence of three kinds of actions on the change of flame characteristics under different conditions. Wang et al. ${ }^{[8]}$ studied the effects of the fuel composition on the evolution of the soot morphology in a methane/acetylene laminar co-flow diffusion flame by using the $\mathrm{SiC}$ fiber deposition method and found that carbon double bond $(\mathrm{C}$ $=\mathrm{C}$ ) was a key factor affecting the soot evolution.

To sum up, in many existing studies, the influence of fuel type, combustion-supporting agent type and other

\footnotetext{
* Corresponding author: Jing $\mathrm{Xu}$

Email: xujing@hhuwtian.edu.cn
}

factors on the distribution law and characteristics of hydrocarbon fuel emission products was mainly analyzed [9-15]. However, there is a lack of systematic elaboration and in-depth study on other characteristics of flame. As shown in Figure 1, the combustion characteristics of hydrocarbon fuel mainly include the following three points: 1. Flame morphology ${ }^{[16,17]} ; 2$. Flame temperature ${ }^{[18]}$;3. Combustion emissions ${ }^{[19]}$. In this paper, an experimental platform for hydrocarbon fuel combustion was built. A thermocouple was used to measure the flame temperature of ethylene, a CCD camera was used to photograph the flame morphology of ethylene combustion, $\mathrm{SiC}$ fiber was used to sample carbon black particles in the flame of ethylene combustion, and SEM was used for characterization analysis. Combustion characteristic rule of ethylene was systematically expounded, which lays a partial foundation for the combustion research of hydrocarbon fuel. 


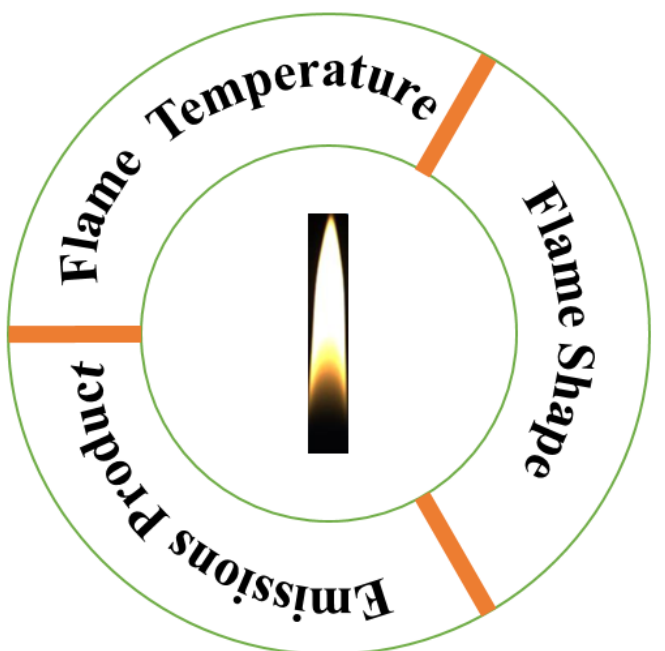

Figure 1. Combustion characteristics of hydrocarbon fuel

\section{Experimental}

\subsection{Laminar flow burner testbed and sampling system}

A Laminar flow burner was employed to investigate the ethylene co-flow laminar diffusion flame under an air environment. Figure 2 shows the experimental platform for ethylene fuel combustion, including laminar flow burner ${ }^{[20]}$, flow meter, CCD camera, and thermocouple. Laminar flow burners are suitable for various hydrocarbon fuels and consist of a fuel tube with an inner diameter of $10.8 \mathrm{~mm}$ and a concentric fuel ring with an inner diameter of $89.0 \mathrm{~mm}$. As the gas flow rate of accelerant is generally higher than that of fuel, the flame can be wrapped to ensure flame stability.

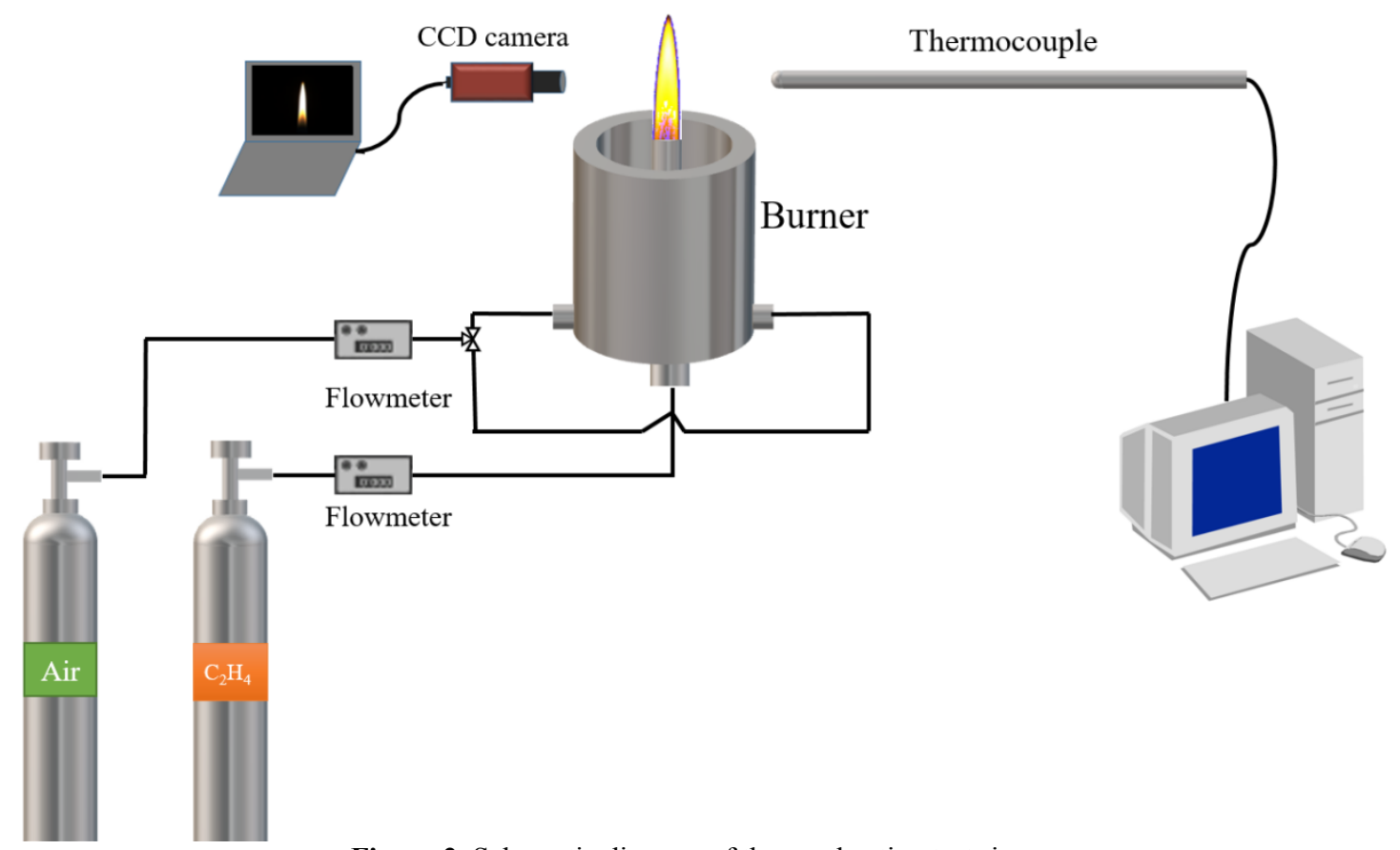

Figure 2. Schematic diagram of the combustion test rig

Figure 3 shows the schematic diagram of the soot particle collection from the combustion emissions of ethylene fuel. The soot particles are collected and sampled at different flame heights using $\mathrm{SiC}$ fiber. $\mathrm{SiC}$ fibers are $100 \mathrm{~mm}$ in length and $15 \mu \mathrm{m}$ in diameter without affecting flame morphology when sampled. Relevant studies ${ }^{[21]}$ have shown that the spacing distance of SiC fibers during sampling will affect the accumulation of soot particles. Therefore, when sampling, the interval distance of $\mathrm{SiC}$ fiber is $20 \mathrm{~mm}$, the axial position soot can be collected, and its morphological characteristics and distribution can be analyzed.

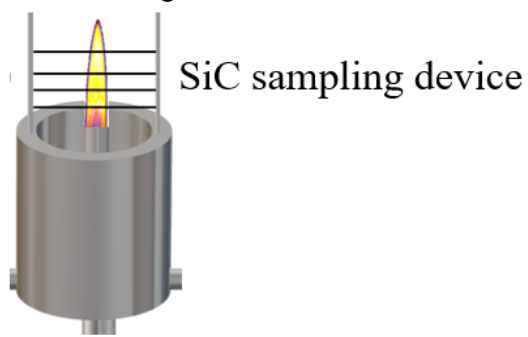

Figure 3. Schematic diagram of $\mathrm{SiC}$ fiber deposition sampling device.

\subsection{Experimental methods and conditions}

Opened the ethylene and air cylinders, and adjust the flow of fuel and accelerant using a flow meter after ignition. A thermocouple was used to measure the temperature of the flame center and the corresponding edge respectively from the bottom of the flame. According to the specific height of the flame, the temperature was measured up to $10 \mathrm{~mm}$ successively 
until it was close to the top. After the measurement, $\mathrm{SiC}$ fiber was placed in the flame to collect the generated soot particles. In order to prevent the $\mathrm{SiC}$ fiber from being burnt out due to long-term combustion, the sampling time was selected to be $120 \mathrm{~s}$. After sampling, SEM was used for characterization to observe the accumulation and morphological characteristics of soot particles at different heights in the axial direction of the flame. Specific combustion conditions are shown in Table 1:

Table 1 Experimental conditions of ethylene-air.

\begin{tabular}{cccc}
\hline Experimental condition & Ethylene flow rate $(\mathrm{ml} / \mathrm{min})$ & Airflow rate(L/min) & $\begin{array}{c}\text { Fuel-air flow } \\
\text { ratio(\%) }\end{array}$ \\
\hline Case1 & 180 & 40 & 0.45 \\
Case2 & 160 & 40 & 0.4 \\
Case3 & 140 & 40 & 0.35 \\
Case4 & 120 & 40 & 0.3 \\
Case5 & 180 & 30 & 0.6 \\
Case6 & 160 & 30 & 0.53 \\
Case7 & 140 & 30 & 0.46 \\
Case8 & 120 & 30 & 0.4
\end{tabular}

\section{Results and discussion}

\subsection{Effects of different conditions on ethylene flame shape}

Figures 4(a) and (b) illustrate the shape of the ethylene flame images at the airflow rate was $30 \mathrm{~L} / \mathrm{min}-40 \mathrm{~L} / \mathrm{min}$ and the ethylene flow rate was $120 \mathrm{ml} / \mathrm{min}-180 \mathrm{ml} / \mathrm{min}$. It can be seen from the figure. 4(a) that when the ethylene flow increased from $120 \mathrm{ml} / \mathrm{min}$ to $180 \mathrm{ml} / \mathrm{min}$, the flame height increased from $5 \mathrm{~cm}$ to $7.2 \mathrm{~cm}$, and the average increase with the flow was $0.062 \mathrm{~cm} /(\mathrm{ml} * \min )$. When the ethylene flow increased from $160 \mathrm{ml} / \mathrm{min}$ to $180 \mathrm{ml} / \mathrm{min}$, the flame height increased to $8.1 \mathrm{~cm}$, and the average increase with the flow was $0.045 \mathrm{~cm} /\left(\mathrm{ml}^{*} \mathrm{~min}\right)$, less than the former. Similarly, it can be obtained from the figure. 4(b) when the ethylene flow increased from $120 \mathrm{~mL} / \mathrm{min}$ to $180 \mathrm{~mL} / \mathrm{min}$, the flame height increased from $5 \mathrm{~cm}$ to $9.1 \mathrm{~cm}$, and the average increase with the flow was $0.068 \mathrm{~cm} /\left(\mathrm{ml}^{*} \mathrm{~min}\right)$. In addition, When the
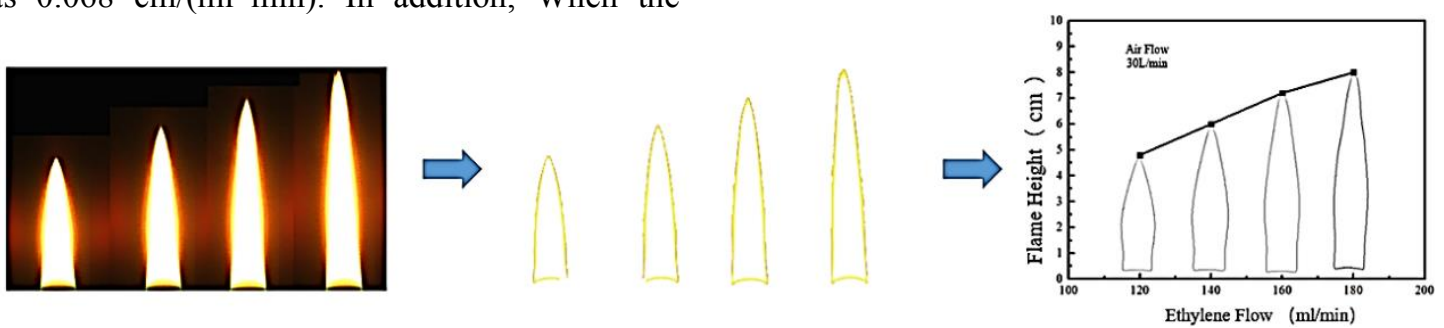

(a)
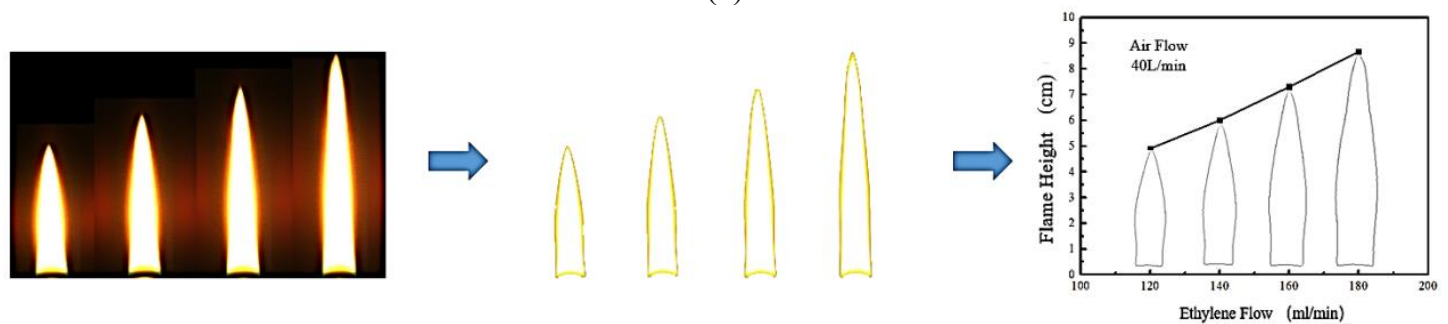

(b) airflow rate was $30 \mathrm{~L} / \mathrm{min}$, the flame height under each flow rate of ethylene was less than that under another condition. These phenomena were because the height of the diffusing flame depends largely on the time required to complete the mixing process. The higher the flow rate of ethylene, the longer the time it takes to mix with air (to reach the chemical equivalent ratio), during which the ethylene molecules will flow through a longer distance, the higher the flame; conversely, the smaller the flow rate of ethylene, which can be mixed with air over a shorter distance, the shorter the flame. In the experiment, because the air enveloped ethylene makes it produces laminar flow, the viscous force between it and ethylene will increase when the air velocity is relatively large, which makes the flow velocity of ethylene increase relatively after the outflow outlet. Moreover, the flame height and the ethylene flow were basically in a linear relationship. It was consistent with the literature ${ }^{[22,23]}$.

Figure 4. Diagram of flame height varying with ethylene flow. (a) ethylene flow: $120 \mathrm{ml} / \mathrm{min}-180 \mathrm{ml} / \mathrm{min}$; air flow:30 L/min; (b) ethylene flow: $120 \mathrm{ml} / \mathrm{min}-180 \mathrm{ml} / \mathrm{min}$; air flow: $40 \mathrm{~L} / \mathrm{min}$. 


\subsection{Effects of different conditions on ethylene flame temperature}

Figure 5 shows the flame temperature at the axial center of the flame at different working conditions and every $10 \mathrm{~mm}$ flame height. On the whole, under all experimental conditions, the temperature at the axial direction of the flame presents a trend of first increasing, then decreasing, and then increasing with the flame height ${ }^{[24]}$. Figure 5 (a) and Figure 5 (b) show the change of ethylene center temperature with height under different fuel flow rates and airflow rates. It can be seen that as the flame height increases, the flame temperature kept rising, and the temperature at the fuel outlet (within the range of $0 \sim 1 \mathrm{~cm}$ ) raised the fastest. The average growth temperature was $400^{\circ} \mathrm{C}$. It was because the ethylene at the outlet of the burner was in the initial pyrolysis state, and had not had time to react with oxygen. After pyrolysis, it diffused to a higher place and reacted violently with oxygen. In Figure 5 (a), when the ethylene flow was $120 \mathrm{ml} / \mathrm{min}$, the temperature reached its maximum at the same flame height, from $679^{\circ} \mathrm{C}$ at $10 \mathrm{~mm}$ to $1046^{\circ} \mathrm{C}$ at $40 \mathrm{~mm}$, the temperature increased by $367^{\circ} \mathrm{C}$, the average growth was $12.23^{\circ} \mathrm{C}$. The same
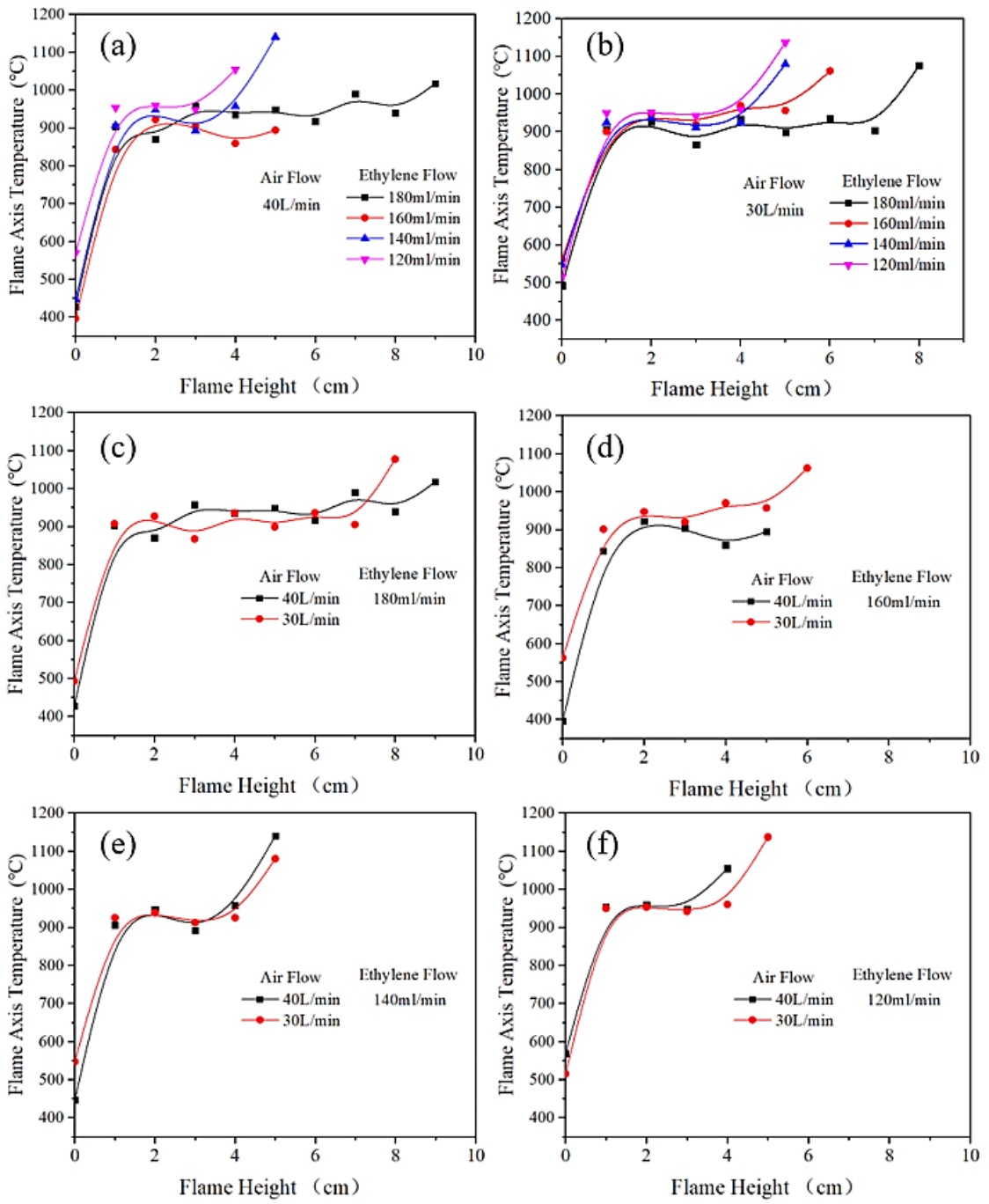
$40 \mathrm{~L} / \mathrm{min}$.

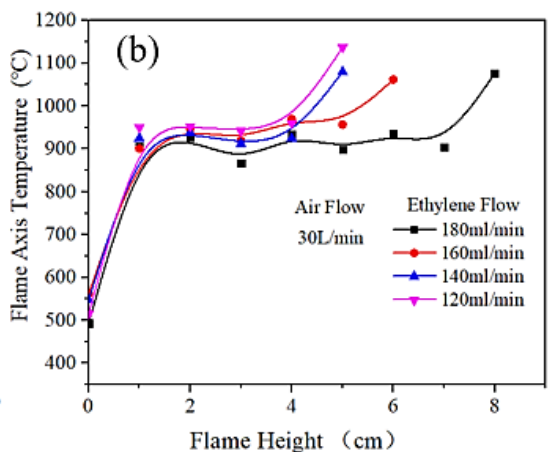

Figure 5. Diagram of flame axis temperature changing with flame height under different working conditions.

phenomenon was observed in Figure $5(\mathrm{~b})$, when the ethylene flow was $120 \mathrm{ml} / \mathrm{min}$, it increased from $557^{\circ} \mathrm{C}$ at $10 \mathrm{~mm}$ to $1158^{\circ} \mathrm{C}$ at $45 \mathrm{~mm}$, increasing by $601^{\circ} \mathrm{C}$, the average growth was $17.17^{\circ} \mathrm{C}$. Furthermore, in Figure 5 (b), the flame temperature at the same height decreased with the increase of ethylene flow, and the average reduction temperature was $50^{\circ} \mathrm{C}$. The main reason was that the flame of hydrocarbon fuel was stratified and there were two different zones: pyrolysis zone and oxidation zone. The pyrolysis zone was blue and the oxidation zone was yellow ${ }^{[25]}$. With the increase of ethylene flow, the flame height increases, while the oxidation zone moves up, that is, the high-temperature zone moves up, so at the lower position, when ethylene flow is low, the central flame temperature is high. By comparing Figure 5 (c), (d), (e), and (f), the temperature changed the trend of flame at different heights was the same under different airflow rates, especially when the ethylene flow rate was $120 \mathrm{ml} / \mathrm{min}$ and $140 \mathrm{ml} / \mathrm{min}$. Moreover, the common feature of these four figures was that when the airflow rate was $30 \mathrm{~L} / \mathrm{min}$, the outlet temperature of the flame center at each flow rate of ethylene is always higher than when the airflow rate was 
In order to demonstrate the effects of different working conditions on flame edge temperature. Figure 6 shows the flame edge temperature distribution corresponding to every $10 \mathrm{~mm}$ height under different working conditions. With the increase of the height, the flame edge temperature increases first and then decreases, and the trend is consistent with the flame center temperature. Figures 6(a) and (b) respectively show the temperature distribution at the flame edge of corresponding height under all experimental conditions. In the flame height of $0 \mathrm{~mm}$, the ethylene flow rate increased from $120 \mathrm{ml} / \mathrm{min}$ to $140 \mathrm{ml} / \mathrm{min}$, the bottom of the flame radius increased by $4 \mathrm{~mm}$ to $4.7 \mathrm{~mm}$, edge temperature from $1030{ }^{\circ} \mathrm{C}$ to $865{ }^{\circ} \mathrm{C}$, the ethylene flow rate increased from $140 \mathrm{ml} / \mathrm{min}$ to $160 \mathrm{ml} / \mathrm{min}$, the bottom of the flame radius reduced from $4.7 \mathrm{~mm}$ to 4 $\mathrm{mm}$, edge temperature from $865{ }^{\circ} \mathrm{C}$ to $695{ }^{\circ} \mathrm{C}$, the ethylene flow rate increased from $160 \mathrm{ml} / \mathrm{min}$ to 180 $\mathrm{ml} / \mathrm{min}$, the bottom of the flame radius increased from 4 $\mathrm{mm}$ to $6 \mathrm{~mm}$, edge temperature from $695{ }^{\circ} \mathrm{C}$ to $665{ }^{\circ} \mathrm{C}$. The changed of the flame radius with the flow rate at the bottom was consistent with the experimental observation. It was important to note that in figure 6 (b), when the airflow of $30 \mathrm{~L} / \mathrm{min}$, the flame height of $0 \mathrm{~mm}$, the ethylene flow rate increased from $120 \mathrm{ml} / \mathrm{min}$ to 140 $\mathrm{ml} / \mathrm{min}$, the bottom of the flame radius increased from
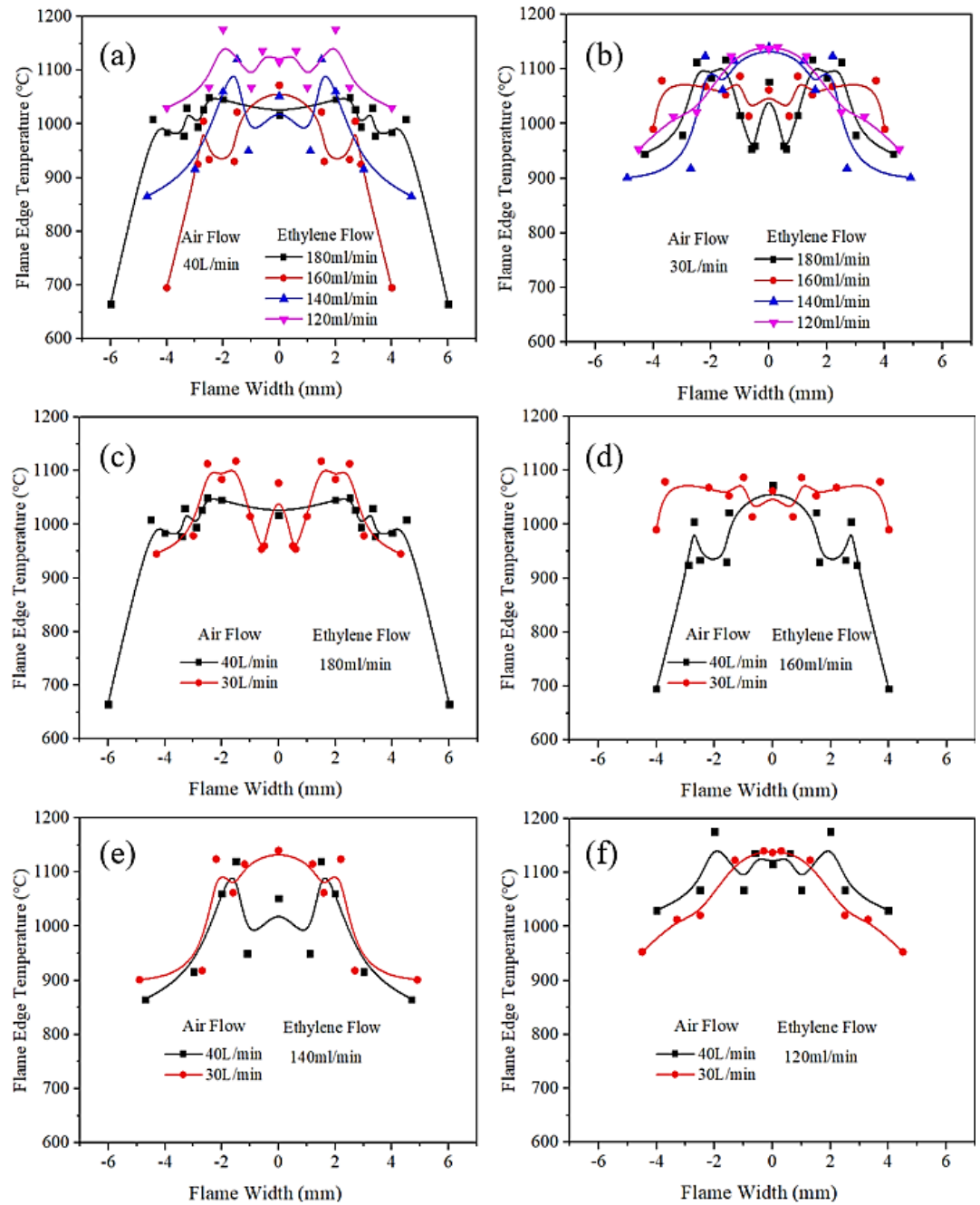

Figure 6. Diagram of flame edge temperature changing with corresponding flame height under different working conditions.

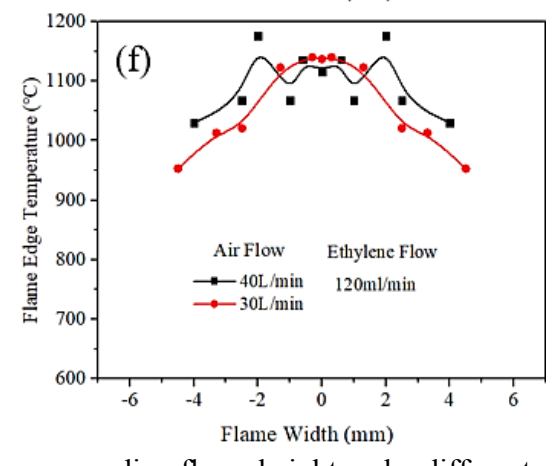

$4.5 \mathrm{~mm}$ to $4.9 \mathrm{~mm}$, edge temperature from $953{ }^{\circ} \mathrm{C}$ to $901{ }^{\circ} \mathrm{C}$, the ethylene flow rate increased from 140 $\mathrm{ml} / \mathrm{min}$ to $160 \mathrm{ml} / \mathrm{min}$, and at the bottom of the flame radius reduced from $4.9 \mathrm{~mm}$ to $4 \mathrm{~mm}$, but the edge temperature from $901{ }^{\circ} \mathrm{C}$ to $990{ }^{\circ} \mathrm{C}$, the ethylene flow rate increased from $160 \mathrm{ml} / \mathrm{min}$ to $180 \mathrm{ml} / \mathrm{min}$, The flame bottom radius increased from $4 \mathrm{~mm}$ to $4.3 \mathrm{~mm}$ and the edge temperature decreased from $990^{\circ} \mathrm{C}$ to $945^{\circ} \mathrm{C}$. In addition, the flame variation trend of the flame radius in the figure 6 (b) was the same as that in figure6. (a), but the variation rule of edge temperature was different. By comparing figures 6 (c), (d), (e), and (f), the author also found an interesting phenomenon. In the conditions listed in the experiment, when the airflow rate was small, the average flame edge temperature was higher. When the airflow rate increased from $30 \mathrm{~L} / \mathrm{min}$ to $40 \mathrm{~L} / \mathrm{min}$, the average flame edge temperature decreased by about $50{ }^{\circ} \mathrm{C}$, mainly because the increase of airflow rate resulted in the increase of convective heat transfer coefficient and the increase of heat taken away by the air, so that the flame edge temperature decreased ${ }^{[26]}$. By comparing figure 5 and figure 6 , it can be seen that under all experimental conditions, the flame edge temperature was always larger than the flame center temperature at the corresponding height, with an average increase of $87.5{ }^{\circ} \mathrm{C}$.

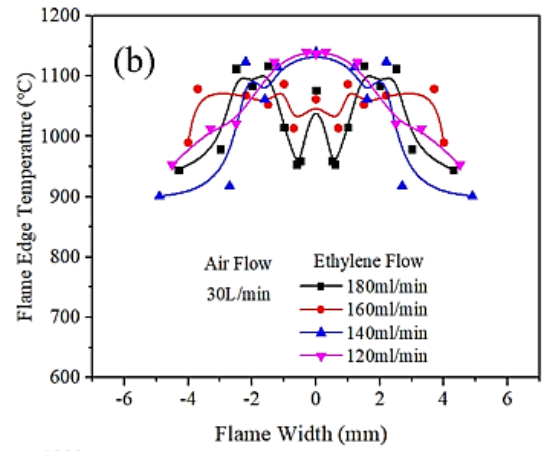



analyzed.

\subsection{Effects of different conditions on ethylene flame emission products}

According to the experimental results of flame height in the previous paper, when the airflow rate was $30 \mathrm{~L} / \mathrm{min}$, $40 \mathrm{~L} / \mathrm{min}$ and the ethylene flow rate was $180 \mathrm{ml} / \mathrm{min}$, $\mathrm{SiC}$ fiber was used for sampling at the central position when the flame height $\mathrm{H}$ was $0 \mathrm{~cm}, 2 \mathrm{~cm}, 4 \mathrm{~cm}$ and $6 \mathrm{~cm}$ respectively. After sampling, the specimens were characterized by scanning electron microscope (SEM), and the formation and distribution of soot particles on $\mathrm{SiC}$ fibers at the center of flame at different heights were

Figure 7 shows the soot particle images at different heights $(0 \mathrm{~cm}, 2 \mathrm{~cm}, 4 \mathrm{~cm}, 6 \mathrm{~cm})$ above the ethylene flame at the same time when the air is $30 \mathrm{~L} / \mathrm{min}$. It can be seen from the figure 7(a) that only a small amount of soot was generated at the height of $\mathrm{H}=0 \mathrm{~cm}$. At the height of $\mathrm{H}=2$ and $\mathrm{H}=4 \mathrm{~cm}$, the soot production reached the maximum, while at the height of $\mathrm{H}=6 \mathrm{~cm}$, the soot production began to decrease. The formation of soot can be roughly divided into the following processes: the formation and growth of polycyclic aromatic hydrocarbons at $\mathrm{H}=0 \mathrm{~cm}$ and the early nucleation of soot particles ${ }^{[27,28]}$. At $\mathrm{H}=2$ $\mathrm{cm}$, the soot particles began to grow, which showed an increase in particle diameter. At $\mathrm{H}=4 \mathrm{~cm}$, the soot particles began to coagulate and coalesced, which was a

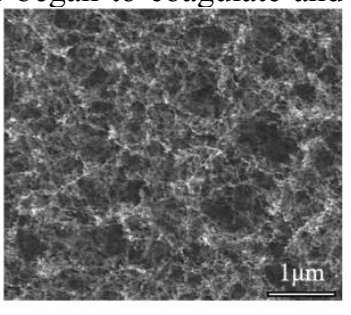

$H=0 \mathrm{~cm}$

(a)

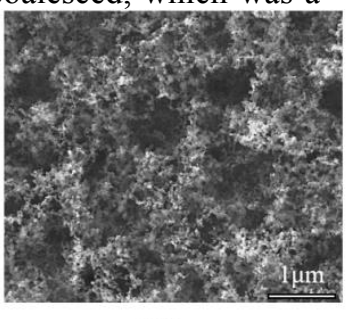

$H=2 \mathrm{~cm}$

(b) physical growth process. At $\mathrm{H}=6 \mathrm{~cm}$, the soot particles undergo an oxidation process, with a smaller diameter and looser structure ${ }^{[29]}$.

Figure 8 shows the soot particle image when the airflow is $40 \mathrm{~L} / \mathrm{min}$, and the sampling height is consistent with that in the figure 7 , the evolution trend of soot particles is consistent with that of air of $30 \mathrm{~L} / \mathrm{min}$. The difference was that the position of soot growth, nucleation, coagulation, and oxidation in flame was delayed due to the increase of airflow and the increase of flame height. By comparing figures 7(d) and figure 8(d), it can be seen that at $\mathrm{H}=6 \mathrm{~cm}$, when the air was $30 \mathrm{~L} / \mathrm{min}$, the flame was close to the top, that is, the oxidation process was almost over, and the soot particles had been oxidized into a more delicate fibrous structure with smaller particle size. However, when the air was 40L $/ \mathrm{min}$, the particle diameter was still relatively large, and nearly $50 \%$ of the soot particles were white, which were non-conductive particles after oxidation. Therefore, we believed that the soot was still in the oxidation stage.

In addition, based on the figure 7 and figure 8 , it can be seen that in the whole combustion process, the generation process of flame soot should be a process of "nucleation - growth - coagulation - oxidation", and the four processes should exist simultaneously at different locations, but with different proportions.

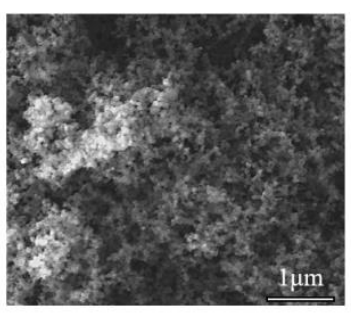

$H=4 \mathrm{~cm}$

(c)

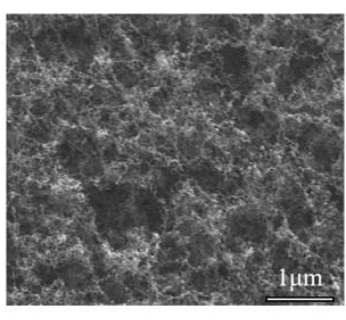

$H=6 \mathrm{~cm}$

(d)

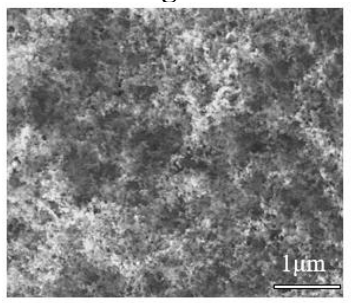

$H=0 \mathrm{~cm}$

(a)

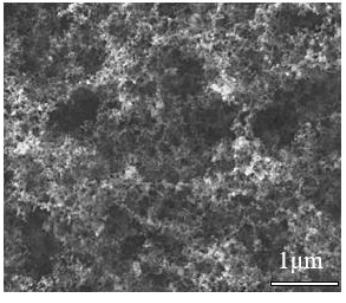

$H=2 \mathrm{~cm}$ (b)

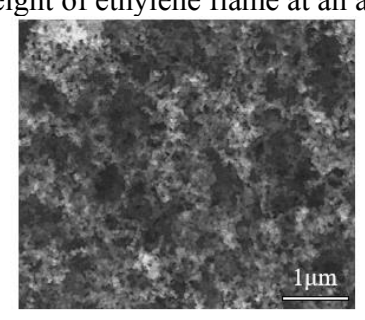

$H=4 \mathrm{~cm}$

(c)

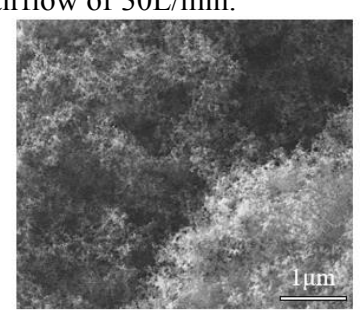

$H=6 \mathrm{~cm}$

(d)

Figure 8. Soot deposition image at different height of ethylene flame at an airflow of $40 \mathrm{~L} / \mathrm{min}$

\section{Conclusions}

A new sampling device was used to study the characteristics of the laminar diffusion flame in the common flow of ethylene, which facilitates a deep understanding of the flame morphology, temperature, soot formation, and oxidation process under different air atmospheres. Different pathways of particle morphological evolution at varying conditions were demonstrated by SEM images. The flame shape and its relationship with soot formation explained the experimental phenomena. Based on the present experimental results, the following conclusions can be drawn:

(1). With the increase of fuel flow, the changing trend of ethylene flame height was consistent under different air atmospheres. When the airflow was $40 \mathrm{~L} / \mathrm{min}$, the flame height was slightly higher than that when the airflow was $30 \mathrm{~L} / \mathrm{min}$. However, when the airflow was $30 \mathrm{~L} / \mathrm{min}$, the average flame radius was slightly higher than that when the airflow was $40 \mathrm{~L} / \mathrm{min}$.

(2). In any condition, the temperature at the center and the temperature at the edge of the ethylene flame increased first, then decreased slightly, and then increased with the increase in height. The flame edge 
temperature is always greater than the flame center temperature at the corresponding height, with an average increase of $87.5^{\circ} \mathrm{C}$.

(3). The different stages of soot formation in ethylene flame (including nucleation, surface growth, coalescence, coalescence, and oxidation) were studied by comparing the changes of soot form and primary particle size at the center of pure ethylene flame under different air atmospheres. In addition, the increase of air also inhibited the formation of soot at different stages, and the higher the airflow, the more obvious the inhibition was.

\section{Acknowledgments:}

This research was funded by University Natural Science Research Project of Anhui Province (Grant No. KJ2019A1278).

\section{References}

1. Hansen, S.; Mirkouei, A.; Diaz, L. A. A comprehensive state-of-technology review for upgrading bio-oil to renewable or blended hydrocarbon fuels. Renewable and Sustainable Energy Reviews. 2020, 118, DOI:10.1016/j.rser.2019.109548.

2. Shu, R.; Li, R.; Lin, B.; Wang, C.; Cheng, Z.; Chen, Y. A review on the catalytic hydrodeoxygenation of lignin-derived phenolic compounds and the conversion of raw lignin to hydrocarbon liquid fuels. Biomass and Bioenergy. 2020, 132, DOI : 10.1016/j.biombioe.2019.105432.

3. Shi, N.; Xie, Y.; Yang, Y.; Xue, S.; Li, X.; Zhu, K.; Huan, D.; Peng, R.; Xia, C.; Lu, Y. Review of anodic reactions in hydrocarbon fueled solid oxide fuel cells and strategies to improve anode performance and stability. Materials for Renewable and Sustainable Energy. 2020, 9, (39), 815-827, DOI:10.1007/s40243-020-0166-8.

4. Rajendran, K. M.; Chintala, V.; Sharma, A.; Pal, S.; Pandey, J. K.; Ghodke, P. Review of catalyst materials in achieving the liquid hydrocarbon fuels from municipal mixed plastic waste (MMPW). Materials Today Communications. 2020, 24, DOI:10.1016/j.mtcomm.2020.100982.

5. Du, D. X.; Axelbaum, R. L.; Law, C. K. The influence of carbon dioxide and oxygen as additives on soot formation in diffusion flames. Symposium (International) on Combustion. 1991, 23, (1), 15011507, DOI: 10.1016/S0082-0784(06)80419-4.

6. Liu, F.; Guo, H.; Smallwood, G. J.; Gülder, Ö. L. The chemical effects of carbon dioxide as an additive in an ethylene diffusion flame: implications for soot and NO x formation. Combust. Flame. 2001, 125 , (1), 778-787, DOI : 10.1016/S00102180(00)00241-8.

7. $\mathrm{Hu}, \mathrm{X}$; Yu, Q.; Liu, J.; Sun, N. Investigation of laminar flame speeds of $\mathrm{CH} 4 / \mathrm{O} 2 / \mathrm{CO} 2$ mixtures at ordinary pressure and kinetic simulation. Energy. 2014, 70, (3), 626-634, DOI : 10.1016/j.energy.2014.04.029.

8. Wang, Y.; Yao, Q. Deposit morphology on SiC fibers in methane-acetylene/air laminar diffusion flames. Korean J. Chem. Eng. 2007, 24, (2), 305310, DOI: 10.1007/s11814-007-5036-x.

9. Glassman, I. Soot formation in combustion processes. Symposium (International) on Combustion. 1989, 22, (1), 295-311, DOI : 10.1016/S0082-0784(89)80036-0.

10. Miller, J. H. The kinetics of polynuclear aromatic hydrocarbon agglomeration in flames. J. Houston Miller. 1991, 23, (1), 91-98, DOI: 10.1016/S00820784(06)80246-8.

11. Saito, K.; Gordon, A. S.; Williams, F. A.; Stickle, W. F. A Study of the Early History of Soot Formation in Various Hydrocarbon Diffusion Flames. Combust. Sci. Technol. 1991, 80, (1-3), 103-119, DOI:10.1080/00102209108951779.

12. C., S. K.; Houston, M. J.; C., D. R.; Gary, M. W.; J., S. R. Soot inception in a methane/air diffusion flame as characterized by detailed species profiles. Smyth Kermit C.;Miller J.Houston;Dorfman Robert C.;Mallard W.Gary;Santoro Robert J. 1985, 62, (2), 157-181, DOI: 10.1016/0010-2180(85)90143-9.

13. C., S. K.; E., H. J.; L., J. E.; M., P. W. Greatly enhanced soot scattering in flickering $\mathrm{CH}_{4} / \mathrm{Air}$ diffusion flames. Smyth Kermit C.;Harrington Joel E.;Johnsson Erik L.;Pitts William M. 1993, 95, (1-2) 229-239, DOI: 10.1016/0010-2180(93)90064-A.

14. Richter, H.; Howard, J. B. Formation of polycyclic aromatic hydrocarbons and their growth to soot-a review of chemical reaction pathways. Prog. Energ. Combust. 2000, 26, (4), 565-608, DOI : 10.1016/S0360-1285(00)00009-5.

15. Ramanathan, V.; Carmichael, G. Global and regional climate changes due to black carbon. Nat. Geosci. 2008, 1, (4), 335-358, DOI : $10.1038 /$ ngeo 156 .

16. Wu, Z.; Kang, Y.; He, X. Numerical Study on the Morphology of a Re-Ignited Laminar Partially Premixed Flame with a Co-Axial Pilot Flame. $J$. Therm. Sci. 2020, 29, (2006), 90-97, DOI:10.1007/s11630-019-1249-7.

17. Kulkarni, T.; Bisetti, F. Surface morphology and inner fractal cutoff scale of spherical turbulent premixed flames in decaying isotropic turbulence. $P$. Combust. Inst. DOI:10.1016/j.proci.2020.06.117

18. Si, M.; Cheng, Q.; Zhang, Q.; Wang, D.; Luo, Z. Simultaneous Reconstruction of the Temperature and Inhomogeneous Radiative Properties of Soot in Atmospheric and Pressurized Ethylene/Air Flames. Combust. Sci. Technol. 2020, 192, (10), 1946-1962, DOI:10.1080/00102202.2019.1632299. 
19. Chu, H.; Han, W.; Cao, W.; Tao, C.; Raza, M.; Chen, L. Experimental investigation of soot morphology and primary particle size along axial and radial direction of an ethylene diffusion flame via electron microscopy. J. Energy Inst. 2019, 92, (5), 1294-1302, DOI:10.1016/j.joei.2018.10.005.

20. Gülder, Ö. L.; Snelling, D. R.; Sawchuk, R. A. Influence of hydrogen addition to fuel on temperature field and soot formation in diffusion flames. Symposium (International) on Combustion. 1996, 26, (2), 2351-2358, DOI : 10.1016/S00820784(96)80064-6.

21. Shim, S. H.; Shin, H. D. Transition morphology of deposits on $\mathrm{SiC}$ fibers in propane/air laminar diffusion flames. Combustion \& Flame. 2002, 131, $(1 / 2), \quad 210-218, \quad$ DOI : $10.1016 / \mathrm{S} 0010-$ 2180(02)00408-X.

22. Sunderland, P. B.; Haylett, J. E.; Urban, D. L.; Nayagam, V. Lengths of laminar jet diffusion flames under elevated gravity. Combustion \& Flame. 2008, 152, (1-2), 60-68, DOI : 10.1016/j.combustflame.2007.08.011.

23. Camacho, J. R.; Choudhuri, A. R. Shapes of Elliptic Methane Laminar Jet Diffusion Flames. Journal of Engineering for Gas Turbines \& Power. 2013, 128, (1), 1-7, DOI: $10.1115 / 1.2032449$

24. Santoro, R. J.; Yeh, T. T.; Horvath, J. J.; Semerjian, H. G. The Transport and Growth of Soot Particles in Laminar Diffusion Flames. Combust. Sci. Technol. 1987, 53, (2-3), 89-115, DOI : $10.1080 / 00102208708947022$.

25. Beltrame, A.; Porshnev, P.; Merchan-Merchan, W.; Saveliev, A.; Fridman, A.; Kennedy, L. A.; Petrova, O.; Zhdanok, S.; Amouri, F.; Charon, O. Soot and NO formation in methane-oxygen enriched diffusion flames. Combust. Flame. 2001, 124, (1), 295-310, DOI:10.1016/S0010-2180(00)00185-1.

26. Han, W.; Ya, Y.; Chu, H.; Cao, W.; Yan, Y.; Chen, L. Morphological evolution of soot emissions from a laminar co-flow methane diffusion flame with varying oxygen concentrations. J. Energy Inst. 2020, 93, (1), 224-234, DOI: 10.1016/j.joei.2019.03.006.

27. Wang, H. A detailed kinetic modeling study of aromatics formation in laminar premixed acetylene and ethylene flames. Combust. Flame. 1997, 110, (1), 173-221, DOI: 10.1016/S0010-2180(97)000680 .

28. Krestinin, A. V. Detailed modeling of soot formation in hydrocarbon pyrolysis. Combust. Flame. 2000, 121, (3), 1559-1566, DOI : 10.1016/S0010-2180(99)00167-4.

29. Boehman, A. L.; Song, J.; Alam, M. Impact of Biodiesel Blending on Diesel Soot and the Regeneration of Particulate Filters. Energ. Fuel. 2005, 19, (5), 1857-1864, DOI: 10.1021/ef0500585. 